\title{
Influence of selected demographic and clinical factors on the treatment of rheumatoid arthritis - a long-term follow-up
}

\author{
Wpływ wybranych czynników demograficznych i klinicznych na przebieg leczenia \\ reumatoidalnego zapalenia stawów - obserwacja długoterminowa
}

\author{
Department of Internal Medicine and Rheumatology, Central Clinical Hospital of the Ministry of National Defence, Military Institute of Medicine, Warsaw, Poland. Head: Professor Witold Thustochowicz, MD, PhD \\ Correspondence: Robert Kruszewski, MD, Department of Internal Medicine and Rheumatology, Central Clinical Hospital of the Ministry of National Defence, Military Institute of Medicine, \\ Szaserów 128, 04-141 Warsaw, Poland, tel.: +48 261817 418, e-mail: rkruszewski@wim.mil.pl
}

Abstract Methotrexate is recommended as a first-line drug in the treatment of rheumatoid arthritis, however, clinical practice often requires a change in the therapeutic approach. Our objective was to evaluate the influence of several demographic and diseaserelated factors on the treatment of rheumatoid arthritis. A group of 143 rheumatoid arthritis patients, initially treated with methotrexate in monotherapy or in combination with glucocorticoids, was followed for an average of 7.5 years. A search for associations between age, sex, disease onset age, disease duration, body mass index, smoking, rheumatoid factor and anticitrullinated protein antibodies status, initial disease activity, bone erosions and rheumatoid arthritis treatment during the follow-up was performed. Patients receiving biological therapy were younger than those on other types of treatment $(50.57 \pm 13.39$ vs. $58.86 \pm 11.67$ years; $p=0.0013)$, had slightly lower disease onset age $(41.78 \pm 13.03$ vs. $47.88 \pm 13.74$ years; $p=0.035)$ and more prevalent high levels of anti-citrullinated protein antibodies ( $91 \%$ vs. $66 \% ; p=0.02)$. On the other hand, patients on methotrexate monotherapy were older than those receiving other therapies (61.51 \pm 10.86 vs. $53.97 \pm 12.61$ years; $p=0.0002)$ and had slightly higher disease onset age ( $52.08 \pm 13.20$ vs. $42.55 \pm 12.82$ years; $p=0.000026$ ). Higher initial disease activity (DAS28) was associated with a need for prolonged treatment with biological agents or biological therapy with addition of synthetic disease modifying antirheumatic drugs other than methotrexate. We found no relationships between sex, disease duration, body mass index, smoking or radiological erosions and the type of received disease modifying antirheumatic drug. Patient's actual age and disease onset age seem to have the most significant impact on rheumatoid arthritis treatment course.

Keywords: rheumatoid arthritis, disease-modifying antirheumatic drugs, methotrexate

Aktualne standardy postępowania rekomendują zastosowanie metotreksatu jako leku pierwszego wyboru w leczeniu reumatoidalnego zapalenia stawów, jednak w praktyce klinicznej nierzadkie są sytuacje wymagające intensyfikacji lub modyfikacji terapii. Celem niniejszej pracy była analiza wpływu wybranych parametrów demograficznych i związanych z chorobą na przebieg leczenia reumatoidalnego zapalenia stawów. Grupę 143 chorych na reumatoidalne zapalenie stawów, wyjściowo leczonych metotreksatem w monoterapii lub w skojarzeniu z glikokortykosteroidami, poddano 7,5-rocznej obserwacji. Przeprowadzono analizę zależności między wybranymi czynnikami (wiek, płeć, wiek zachorowania, czas trwania choroby, wskaźnik masy ciała, palenie papierosów, obecność i stężenia czynnika reumatoidalnego oraz przeciwciał przeciwko cyklicznemu cytrulinowanemu peptydowi, aktywność choroby, obecność zmian radiologicznych) a rodzajem leczenia stosowanego w okresie obserwacji. Chorzy, u których włączono leczenie biologiczne, byli istotnie młodsi w porównaniu z chorymi leczonymi innymi metodami $(50,57 \pm 13,39$ $v s 58,86 \pm 11,67$ roku; $p=0,0013)$, cechowali się niższym wiekiem zachorowania $(41,78 \pm 13,03$ ss 47,88 $\pm 13,74$ roku; $p=0,035)$ oraz częstszym występowaniem wysoko pozytywnych przeciwciał przeciwko cyklicznemu cytrulinowanemu peptydowi (91\% vs $66 \% ; p=0,02$ ). Chorzy leczeni metotreksatem w monoterapii byli starsi w porównaniu z pacjentami leczonymi innymi metodami $(61,51 \pm 10,86 v s 53,97 \pm 12,61$ roku; $p=0,0002)$ i później zapadali na reumatoidalne zapalenie stawów $(52,08 \pm 13,20 v s$ 42,55 \pm 12,82 roku; $p=0,000026$ ). Wyższa wyjściowa aktywność choroby (według DAS28) wiązała się z częstszą potrzebą długotrwałego stosowania leków biologicznych w monoterapii lub w skojarzeniu z klasycznym syntetycznym lekiem modyfikującym przebieg choroby innym niż metotreksat. Nie zaobserwowano związku między płcią, czasem trwania choroby, wskaźnikiem masy ciała, paleniem papierosów, obecnością zmian radiologicznych a stosowanymi lekami modyfikującymi. Wiek pacjenta oraz wiek, w jakim zachorował, wydają się wywierać najwyraźniejszy wpływ na przebieg leczenia reumatoidalnego zapalenia stawów. 


\section{INTRODUCTION}

$\mathrm{R}$ heumatoid arthritis (RA) is a chronic autoimmune inflammatory disease. It is characterised by painful joint swelling and may with time result in permanent joint damage and, consequently, disability ${ }^{(1)}$. According to various sources, the prevalence of RA is estimated at $0.5-1.5 \%{ }^{(2)}$. Despite extensive research on the underlying mechanisms of the disease, the aetiology is still not fully understood.

The management of RA, as a chronic disease, involves the use of disease-modifying antirheumatic drugs (DMARDs) to achieve remission or, if this is not possible, at least low disease activity. Additionally, glucocorticoids (GCs) or non-steroidal anti-inflammatory drugs (NSAIDs) are used, if needed, to relieve the symptoms. Disease-modifying therapy should be initiated immediately after the diagnosis. DMARDs are classified as conventional synthetic drugs (csDMARDs), such as methotrexate (MTX), leflunomide (LEF), sulphasalazine (SSZ), and biologics (bDMARDs), such as e.g. tumour necrosis factor (TNF) inhibitors, tocilizumab or rituximab. Also, a group of targeted synthetic DMARDs (tsDMARDs), including Janus kinase (JAK) inhibitors, such as tofacitinib, baricitinib, has been distinguished.

Over the past several decades, methotrexate has become the first-line treatment for $\mathrm{RA}^{(3)}$. Its efficacy and safety have been confirmed and compared to other forms of therapy in many scientific papers, which is reflected in the guidelines developed by scientific societies.

The European League Against Rheumatism (EULAR) systematically updates the recommendations on the treatment of RA, with their first version published in $2010^{(1)}$. These recommendations are a summary of the currently available knowledge based on published clinical trials and expert opinions. Their implementation in the clinical practice assists in the choice of optimal treatment strategy, taking into account therapeutic safety and efficacy, as well as the pharmacoeconomic aspect.

The treat-to-target strategy, the aim of which is to achieve disease remission or low activity, has been established as the primary principle for the treatment of $\mathrm{RA}^{(1,4,5)}$. It involves gradual treatment modification if the desired effect is not achieved. It is generally recommended to use MTX as the first-line treatment, and, in the case of ineffectiveness or contraindications, include another csDMARD in combination with MTX or as a monotherapy. The next line of treatment involves the use of bDMARDs or tsDMARDs, either in combination with csDMARDs or as a monotherapy. Failure to achieve the therapeutic goal at this stage is associated with the need for further changes of the agents within the same class, taking into account their mechanisms of action and safety profiles. Furthermore, factors correlated with an unfavourable prognosis (high levels of rheumatoid factor - RF - and anti-citrullinated protein antibody ACPA - persistently high disease activity, early erosions in radiography or failure of two csDMARDs), which indicate the need for rapid treatment escalation ${ }^{(1)}$, i.e. the introduction of a bDMARD or a tsDMARD as the second-line treatment, have been identified.

Therefore, it is common for RA patient to receive several different types of therapy before achieving low disease activity or remission. In most cases, regular rheumatological follow-up as well as prompt and adequate treatment modification allow to reach the therapeutic goal and avoid disease complications. However, delays in therapy modification may be associated with prolonged inflammation of the joints, and consequently with their permanent damage. Furthermore, this often leads to chronic use of NSAIDs or GCs, and contributes to a wide spectrum of drug-induced adverse effects. It should be emphasised at this point that the current EULAR recommendations support the use of GCs for no longer than 3 months in the initial stage of the disease $^{(1)}$.

\section{AIM OF THE PAPER}

The aim of this study was to assess the impact of selected demographic and disease-related factors on the choice and course of treatment in patients with RA.

\section{MATERIALS AND METHODS}

The study included 230 adult RA patients hospitalised in the Department of Internal Medicine and Rheumatology of the Military Institute of Medicine in 2008-2013, who met the 1987 classification criteria of the American College of Rheumatology $(\mathrm{ACR})^{(6)}$. This was an observational, non-interventional study. The consent to participate in the study had no influence on the choice of treatment strategy. Each patient gave informed consent to participate in the research. The study was approved by the Bioethics Committee of the Military Institute of Medicine. At enrolment, all patients were on MTX alone or in combination with GCs. Most patients continued further treatment in their place of residence.

The study design included two analyses: at enrolment and after a mean of $7.5 \pm 1.5$ years of follow-up, when an attempt to contact the study participants was made. The questionnaire completed at baseline by all patients inquired about demographic data, such as age, sex, body weight and height, as well as RA duration, age at diagnosis, smoking habits and treatment used. Furthermore, disease activity was assessed using the disease activity score (DAS28) - versions based on the erythrocyte sedimentation rate (ESR) and C-reactive protein (CRP) levels. The used laboratory parameters, i.e. ESR, CRP, RF and ACPA were measured with standard methods in the Department of Laboratory Diagnostics at the Military Institute of Medicine. RF $>35 \mathrm{IU} / \mathrm{mL}$ and ACPA $>10 \mathrm{U} / \mathrm{mL}$ were considered positive; RF and ACPA 3 times the upper limit of normal were considered highpositive. Furthermore, standard AP hand and AP and lateral 


\begin{tabular}{|c|c|}
\hline Age [years] $(n=143)$ & $57.24(12.42)$ \\
\hline Sex (males) $(n=143)$ & $23(16.08 \%)$ \\
\hline BMI $\left[\mathrm{kg} / \mathrm{m}^{2}\right](n=139)$ & $26.28(4.57)$ \\
\hline Age at onset [years] $(n=143)$ & $46.68(13.78)$ \\
\hline Disease duration [years] $(n=143)$ & $10.58(9.00)$ \\
\hline Smoking $(n=143)$ & $20(14 \%)$ \\
\hline $\operatorname{ESR}[\mathrm{mm} / \mathrm{h}](n=143)$ & $33.52(26.13)$ \\
\hline $\operatorname{CRP}[\mathrm{mg} / \mathrm{dL}](n=143)$ & $2.3(3.28)$ \\
\hline Positive RF $(n=139)$ & $104(72.72 \%)$ \\
\hline RF level [IU/mL] $(n=139)$ & $291.18(512.62)$ \\
\hline Strongly positive $\mathrm{RF}^{*}(n=138)$ & $76(53.14 \%)$ \\
\hline Positive ACPA $(n=123)$ & $95(66.43 \%)$ \\
\hline ACPA level $[\mathrm{U} / \mathrm{mL}](n=123)$ & $221.42(279.94)$ \\
\hline Strongly positive $\mathrm{ACPA}^{*}(n=122)$ & $86(60.13 \%)$ \\
\hline DAS28-ESR $(n=142)$ & $4.91(1.53)$ \\
\hline DAS28-CRP $(n=142)$ & $4.53(1.49)$ \\
\hline Radiological joint erosions $(n=116)$ & $88(55.94 \%)$ \\
\hline MTX dose [mg/week] $(n=142)$ & $20.72(5.37)$ \\
\hline Follow-up period [years] $(n=143)$ & $7.6(1.48)$ \\
\hline \multicolumn{2}{|c|}{$\begin{array}{l}\text { Data presented as mean (standard deviation) for continuous variables } \\
\text { and number (\%) for nominal variables. Some data were not available } \\
\text { to all patients. } \\
\text { * }>3 \text { times the upper limit of normal (RF standard: }<35 \mathrm{IU} / \mathrm{mL} \text {; } \\
\text { ACPA standard: }<7 \mathrm{U} / \mathrm{mL} \text { - negative, }>10 \mathrm{U} / \mathrm{mL} \text { - positive). } \\
\text { ACPA - anti-citrullinated protein antibody; BMI - body mass index; } \\
\text { CRP - C-reactive protein; DAS28 - disease activity score; ESR - erythrocyte } \\
\text { sedimentation rate; RF - rheumatoid factor. }\end{array}$} \\
\hline
\end{tabular}

Tab. 1. Characteristics of patients controlled at enrolment $(\mathrm{n}=143)$

foot radiographs were taken and assessed by an experienced radiologist in the Department of Radiology at the Military Institute of Medicine to assess radiographic hallmarks of RA. Follow-up visits were conducted using a telephone questionnaire, a direct conversation during the stay at the Department of Rheumatology of the Military Institute of Medicine or the available medical records. As a result, complete information on the course of RA treatment was obtained from 143 out of 230 patients included in the study. The obtained data were analysed statistically using Statistica 12.0 for Windows (StatSoft). The Student's $t$-test or the Mann-Whitney $U$ test (depending on the normality of the distribution) was used for continuous variables and the Chi-square test was used for nominal (discontinuous) variables. A $p<0.05$ was considered statistically significant (Tab. 1).

\section{RESULTS}

The follow-up questionnaire was conducted among 143 of 230 patients included in the study (62\% of the study group). This was mainly due to out-of-date contact details. Nine patients (6.29\%) died during the follow-up period. None of the patients interviewed refused further participation in the study.

MTX alone or in combination with another DMARD was differences in the assessed parameters were found between patients on MTX (as monotherapy or in combination with other drugs) during the follow-up period compared to those who discontinued this agent.

The mean age of patients on biological treatment $(n=28)$ was lower than that of patients who had never received this type of treatment $(50.57 \pm 13.39$ vs. $58.86 \pm 11.67$ years, respectively; $p=0.0013$ ). This group was also characterised by a lower mean age at disease onset $(41.78 \pm 13.03$ vs. $47.88 \pm 13.74$ years, respectively; $p=0.035$ ). Strongly positive ACPA was significantly more common in these patients ( $91 \%$ vs. $66 \% ; p=0.02)$. However, the presence of ACPA or RF alone was not significantly correlated with the use of biologics. Lower mean age was also found in the group of patients who received biologics for more than half of the follow-up period $(n=13)$ compared to other patients $(49.38 \pm 11.61$ vs. $58.03 \pm 12.27$ years, respectively; $p=0.016)$. They were also characterised by significantly higher mean DAS28 scores at enrolment, calculated both for $\operatorname{ESR}(5.92 \pm 1.64$ vs. $4.80 \pm 1.49 ; p=0.012)$ and CRP $(5.52 \pm 1.51$ vs. $4.43 \pm 1.46 ; p=0.012)$.

The use of GCs throughout the follow-up period and for more than half of this period was reported by 69 (48\%) and 97 (68\%) patients, respectively. Among these patients, 13 (9\%) individuals chronically used prednisone at $>5 \mathrm{mg}$ daily. The mean age of patients receiving GCs for more than half of the follow-up period was lower compared to other patients $(55.25 \pm 12.35$ vs. $61.41 \pm 11.63$ years; $p=0.0053)$. This group was also characterised by a lower mean age at disease onset compared to other patients $(44.34 \pm 13.54$ vs. $51.63 \pm 13.09$ years; $p=0.002)$ and a lower body mass in$\operatorname{dex}(\mathrm{BMI})(25.71 \pm 4.41$ vs. $27.46 \pm 4.72 ; p=0.034)$. No relationship was found between long-term use of GCs and the type of DMARD used in the study group.

The following subgroups of patients were distinguished in the study population based on the treatment used at the time of follow-up:

1. MTX monotherapy - 62 patients $(43 \%)$;

2. Other csDMARD - $21(14 \%)$;

3. MTX plus other csDMARD - $28(20 \%)$

4. MTX plus bDMARD - 17 (12\%);

5. bDMARD monotherapy - $3(2 \%)$;

6. csDMARD other than MTX plus bDMARD - $8(6 \%)$;

7. GCs alone $-4(3 \%)$.

Of the followed-up patients, 6 patients (4\%) reported remission after complete treatment discontinuation; they were assigned to subgroups based on their last therapeutic regimen. Each of such subgroups was compared with other patients for the distribution of the assessed parameters.

Patients treated with MTX alone were on average older than other patients $(61.51 \pm 10.86$ vs. $53.97 \pm 12.61$ years, respectively; $p=0.0002)$. The disease onset occurred at a later age in this group ( $52.08 \pm 13.20$ vs. $42.55 \pm 12.82$ years, respectively; $p=0.000026$ ). No significant differences were found in the distribution of other assessed parameters between this group and other patients. 


\begin{tabular}{|c|c|c|c|}
\hline Parameter & Patients on bDMARD $(n=28)$ & Patients on other forms of therapy $(n=115)$ & $p$ \\
\hline Age [years] $(n=143)$ & $50.57(13.39)$ & $58.86(11.67)$ & 0.0013 \\
\hline Sex (male) $(n=143)$ & $7(25 \%)$ & $16(13.91 \%)$ & 0.15 \\
\hline $\mathrm{BMI}\left[\mathrm{kg} / \mathrm{m}^{2}\right](n=139)$ & $26.43(4.93)$ & $26.43(4.51)$ & 0.85 \\
\hline Age at onset [years] $(n=143)$ & $41.78(13.03)$ & $47.88(13.74)$ & 0.035 \\
\hline Disease duration [years] $(n=143)$ & $8.80(8.91)$ & $11.01(8.9890)$ & 0.24 \\
\hline Smoking $(n=143)$ & $3(11 \%)$ & $17(15 \%)$ & 0.57 \\
\hline Positive RF $(n=139)$ & $85(75 \%)$ & $19(73 \%)$ & 0.82 \\
\hline $\mathrm{RF}[\mathrm{IU} / \mathrm{mL}](n=139)$ & $334.61(423,98)$ & $281.19(532.09)$ & 0.63 \\
\hline $\operatorname{High~RF}^{*}(n=139)$ & $18(69 \%)$ & $58(52 \%)$ & 0.10 \\
\hline Positive ACPA ( $n=123)$ & $20(91 \%)$ & $75(74 \%)$ & 0.09 \\
\hline $\mathrm{ACPA}[\mathrm{U} / \mathrm{mL}](n=123)$ & $299.06(198,11)$ & $204.50(292.83)$ & 0.15 \\
\hline High ACPA* $(n=122)$ & $20(91 \%)$ & $66(66 \%)$ & 0.02 \\
\hline DAS28-ESR $(n=142)$ & $5.41(1.68)$ & $4.78(1.48)$ & 0.054 \\
\hline DAS28-CRP $(n=142)$ & $5.09(1,57)$ & $4.39(1.45)$ & 0.027 \\
\hline Radiological joint erosions ( $n=116)$ & $14(64 \%)$ & $66(70 \%)$ & 0.54 \\
\hline \multicolumn{4}{|c|}{$\begin{array}{l}\text { Data presented as mean (standard deviation) for continuous variables and number }(\%) \text { for nominal variables. Some data were not available to all patients. } \\
*>3 \text { times the upper limit of normal (RF standard: }<35 \mathrm{IU} / \mathrm{mL} ; A \text { ACPA standard: }<7 \mathrm{U} / \mathrm{mL}-\text { negative, }>10 \mathrm{U} / \mathrm{mL} \text { - positive). } \\
\text { ACPA - anti-citrullinated protein antibody; BMI - body mass index; CRP - C-reactive protein; DAS28 - disease activity score; ESR - erythrocyte sedimentation rate; } \\
\mathbf{R F} \text { - rheumatoid factor. }\end{array}$} \\
\hline
\end{tabular}

Tab. 2. Comparison of patients receiving bDMARDs versus patients who never received biologic therapy

Higher RF levels were found in the group of patients on MTX plus other synthetic DMARD compared to other patients (mean $466.28 \pm 940.42$ vs. $247.01 \pm 320.65 \mathrm{IU} / \mathrm{L}$; $p=0.04$ ). The other compared parameters did not differ significantly between the groups.

There were no statistically significant differences between patients on csDMARD other than MTX and other patients. Patients on MTX plus bDMARD were on average younger than the rest of the study participants $(49.23 \pm 11.73 \mathrm{vs}$. $58.32 \pm 12.15$, respectively; $p=0.0042$ ), but no significant difference in the age at RA onset was observed. The other compared parameters did not differ significantly between these groups.

Similarly, the mean age of patients on bDMARD monotherapy was lower compared to other patients, but the difference was not statistically significant $(47.66 \pm 15.3$ vs. $57.45 \pm 12.34$, respectively; $p=0.17$ ). There were also no significant differences between this group and other patients in the distribution of other assessed parameters.

However, the group of patients on csDMARD other than MTX in combination with bDMARD showed higher disease activity, as evidenced by DAS28-ESR and DAS28-CRP. Although the differences reached a score of 1 (DAS28-ESR $5.85 \pm 1.53$ vs. $4.85 \pm 1.52 ; p=0.07$ and DAS28-CRP $5.48 \pm 1.59$ vs. $4.48 \pm 1.48 ; p=0.06$ ), they were not statistically significant. Statistical analysis showed no differences between this group and other patients in the distribution of other assessed parameters.

No differences were observed in the assessed parameters between patients who received GCs alone during the follow-up and other patients.

During the follow-up period, 27 (19\%) out of 143 patients needed at least 3 different DMARDs. Four patients (2\%) in this group received at least 5 different agents as mono- or polytherapy. However, no statistically significant relationships were found between the analysed parameters and the number of drugs used (Tab. 2).

\section{DISCUSSION}

This study involved a mean of 7.5 years of follow-up in 143 RA patients who were on MTX at baseline. After this time, less than half of the patients continued this treatment without any modifications. However, it should be noted that almost $75 \%$ of patients continued MTX either alone or in combination with other DMARD. This is undoubtedly a positive phenomenon given the role of MTX in the treatment of RA, which is emphasised in the recommendations. Among the assessed parameters, patient's actual age and age at disease onset seem to be the most important factors for the course of RA treatment. Younger patients were more likely to require bDMARDs and to receive long-term GCs. This may be due to the lighter course of RA in the elderly, as suggested by some authors, or the reluctance of rheumatologists to escalate the therapy due to their concerns about the higher risk of complications and more severe comorbidities in this group of patients ${ }^{(7,8)}$. According to data from the Consortium of Rheumatology Researchers of North America (CORRONA), patients who developed RA later in life (after the age of 60 years) are more likely to stay on MTX and less likely to report adverse effects, regardless of disease activity or duration. Furthermore, biological treatment or polytherapy is used less frequently in this group of patients ${ }^{(9)}$, which is also confirmed by other studies ${ }^{(10)}$. Our findings agree with these observations. It should be noted, however, that Turkish researchers found a similar 
percentage of reported adverse reactions in patients receiving long-term csDMARD treatment in both early and lateonset $\mathrm{RA}^{(11)}$.

Despite the emphasised importance of ACPA and RF as prognostic factors, it is not recommended to choose the type of therapy in the initial phase of RA treatment solely based on these indicators ${ }^{(12)}$. Our analysis showed no wider relationship between the presence of autoantibodies and the type of treatment used in the study group. More common high ACPA titres in patients on bDMARDs and higher RF levels in patients on csDMARD plus MTX were exceptions, but the difference was on the borderline of statistical significance in the latter case $(p=0.04)$. The IMPROVED study showed a correlation between RF positivity and lower odds of remission in the initial treatment phase (3-6 months), but no such relationship was observed for ACPA, which, however, was associated with a higher risk of relapse after treatment discontinuation or dose reduction ${ }^{(13)}$. An inverse correlation between the presence of RF and the odds of remission within 16-24 months of treatment onset was also found in the ARCTIC study ${ }^{(14)}$. On the other hand, the RETRO study confirmed a higher risk of relapse in ACPA-positive patients after treatment discontinuation or dose reduction, regardless of the type of therapy used (csDMARD or bDMARD) ${ }^{(15)}$. However, the conclusions obtained from a follow-up of a group of over 1,826 RA patients initially treated with MTX in the METEOR study did not confirm the relationship between RF or ACPA positivity and achieving remission in the first 3-6 months ${ }^{(16)}$. Although the available publications indicate no relationship between the presence of autoantibodies and the response to treatment with TNF inhibitors ${ }^{(17)}$, there are reports showing a beneficial effect of autoantibodies on the efficacy of rituximab treatment ${ }^{(18)}$.

Early radiological progression is considered an unfavourable prognostic factor in $\mathrm{RA}^{(1)}$. Our findings did not show a significant impact of early radiological progression on the course of treatment, including the need to intensify the therapy. This is consistent with some authors indicating that the presence of erosions does not necessarily affect the odds for remission or low disease activity ${ }^{(19)}$.

A relatively high percentage of patients in the study group reported long-term or prolonged treatment with GCs. However, this cannot be clearly explained based on the obtained results. Nevertheless, it should be noted that these were younger patients with a lower mean age at onset and a lower BMI. On the other hand, there were no differences in RF and ACPA positivity, baseline disease activity or the type of DMARD used. It can therefore be assumed that this effect is not related to the severity or the course of the disease. Although prednisone doses generally did not exceed $5 \mathrm{mg}$, this is in disagreement with the EULAR recommendations for the treatment of RA. On the other hand, Strehl et al. suggested a good safety profile of long-term use of prednisone at doses $<5 \mathrm{mg}$ per day in their meta-analysis ${ }^{(20)}$.
Studies assessing the current trends in the use of GCs in RA patients have shown that approximately $30-50 \%$ of patients are on long-term glucocorticoid therapy ${ }^{(21,22)}$. This may result from the pressure of young, active patients to minimise their symptoms, regardless of the long-term treatment consequences.

The parameters assessed in our study certainly do not exhaust the list of factors that may affect the course of RA treatment. Since most of the patients' data were obtained through a telephone questionnaire, direct examination of the joints was not possible. For this reason, the post-treatment disease activity was not evaluated in a reliable way. It should also be noted that the relatively long follow-up period resulted in the loss of contact with nearly $1 / 3$ of patients, who could not participate in the follow-up visit, even by phone.

Further research and analyses are undoubtedly needed to assess the course of RA treatment. This is reflected in the continuously increasing number of scientific publications on the therapeutic efficacy and safety, disease activity, disability and improvement in the quality of life of patients, as well as the impact of RA treatment on comorbidities ${ }^{(23)}$. A particular value is attributed to analyses reflecting the actual efficacy of this treatment, which, although conducted under doctor's supervision, should consider not only the guidelines, but also patient's preferences, which are very often based on questionable information found on the Internet. New possibilities that have emerged with the introduction of biologics and JAK inhibitors have made it possible to reduce the effects of RA in patients who do not achieve satisfactory outcomes with csDMARD therapy. It should be noted, however, that it is MTX, classified as csDMARD, that still remains the anchor treatment for RA. Better knowledge of factors that determine the treatment response could contribute to a more rapid implementation of effective therapy in patient groups that fail to achieve the expected improvement in accordance with the treat-to-target principle, as emphasised in the 2019 EULAR recommendations ${ }^{(1)}$. This is also important due to the suggested impact of early intensive treatment in the initial stage of RA on the long-term prognosis ${ }^{(24)}$.

\section{CONCLUSIONS}

It can be concluded based on our findings that patient's actual age and disease onset age seem to have a significant impact on the course of treatment. In addition, older patients are more likely to continue MTX therapy and less likely to use biologics. On the other hand, the use of biologics, including long-term treatment (i.e. for more than half of the follow-up period), is more common in younger patients with high ACPA levels ( $>3$ times the upper limit of normal) and higher disease activity. Sex, disease duration, smoking, RF and ACPA positivity or radiological erosions do not correlate with the type of treatment used. 


\section{Conflict of interest}

The authors do not report any financial or personal connections with other persons or organisations, which might negatively affect the contents of this publication and/or claim authorship rights to this publication.

\section{References}

1. Smolen JS, Landewé RBM, Bijlsma JWJ et al.: EULAR recommendations for the management of rheumatoid arthritis with synthetic and biological disease-modifying antirheumatic drugs: 2019 update. Ann Rheum Dis 2020; 79: 685-699.

2. Tobón GJ, Youinou P, Saraux A: The environment, geo-epidemiology, and autoimmune disease: rheumatoid arthritis. J Autoimmun 2010; 35: 10-14.

3. Pincus T, Yazici Y, Sokka T et al.: Methotrexate as the "anchor drug" for the treatment of early rheumatoid arthritis. Clin Exp Rheumatol 2003; 21 (Suppl 31): S179-S185.

4. Smolen JS, Breedveld FC, Burmester GR et al.: Treating rheumatoid arthritis to target: 2014 update of the recommendations of an international task force. Ann Rheum Dis 2016; 75: 3-15.

5. Singh JA, Saag KG, Bridges SL Jr et al.: 2015 American College of Rheumatology guideline for the treatment of rheumatoid arthritis. Arthritis Rheumatol 2016; 68: 1-26.

6. Arnett FC, Edworthy SM, Bloch DA et al.: The American Rheumatism Association 1987 revised criteria for the classification of rheumatoid arthritis. Arthritis Rheum 1988; 31: 315-324.

7. Corrigan AB, Robinson RG, Terenty TR et al.: Benign rheumatoid arthritis of the aged. Br Med J 1974; 1: 444-446.

8. Innala L, Berglin E, Möller B et al.: Age at onset determines severity and choice of treatment in early rheumatoid arthritis: a prospective study. Arthritis Res Ther 2014; 16: R94.

9. Tutuncu Z, Reed G, Kremer J et al.: Do patients with older-onset rheumatoid arthritis receive less aggressive treatment? Ann Rheum Dis 2006; 65: 1226-1229.

10. Richter MD, Matteson EL, Davis JM $3^{\text {rd }}$ et al.: Comparison of biologic discontinuation in patients with elderly-onset versus younger-onset rheumatoid arthritis. ACR Open Rheumatol 2019; 1: 627-631.

11. Alpay-Kanitez N, Pehlivan Ö, Omma A et al.: Favorable retention rates and safety of conventional anti-rheumatic drugs in older patients with rheumatoid arthritis. Medicine (Baltimore) 2020; 99: e19696.

12. Bugatti S, Manzo A, Montecucco $C$ et al.: The clinical value of autoantibodies in rheumatoid arthritis. Front Med (Lausanne) 2018; 5: 339.
13. Wevers-de Boer K, Visser K, Heimans L et al.: Remission induction therapy with methotrexate and prednisone in patients with early rheumatoid and undifferentiated arthritis (the IMPROVED study). Ann Rheum Dis 2012; 71: 1472-1477.

14. Paulshus Sundlisæter N, Olsen IC, Aga AB et al.; ARCTIC study group: Predictors of sustained remission in patients with early rheumatoid arthritis treated according to an aggressive treat-totarget protocol. Rheumatology (Oxford) 2018; 57: 2022-2031.

15. Haschka J, Englbrecht M, Hueber AJ et al.: Relapse rates in patients with rheumatoid arthritis in stable remission tapering or stopping antirheumatic therapy: interim results from the prospective randomised controlled RETRO study. Ann Rheum Dis 2016; 75: 45-51.

16. Dekkers JS, Bergstra SA, Chopra A et al.: Autoantibody status is not associated with early treatment response to first-line methotrexate in patients with early rheumatoid arthritis. Rheumatology (Oxford) 2019; 58: 149-153.

17. Lv Q, Yin Y, Li X et al.: The status of rheumatoid factor and anticyclic citrullinated peptide antibody are not associated with the effect of anti-TNFa agent treatment in patients with rheumatoid arthritis: a meta-analysis. PLoS One 2014; 9: e89442.

18. Isaacs JD, Cohen SB, Emery P et al.: Effect of baseline rheumatoid factor and anticitrullinated peptide antibody serotype on rituximab clinical response: a meta-analysis. Ann Rheum Dis 2013; 72: 329-336.

19. Baganz L, Richter A, Albrecht $K$ et al.: Are prognostic factors adequately selected to guide treatment decisions in patients with rheumatoid arthritis? A collaborative analysis from three observational cohorts. Semin Arthritis Rheum 2019; 48: 976-982.

20. Strehl C, Bijlsma JWJ, de Wit M et al.: Defining conditions where long-term glucocorticoid treatment has an acceptably low level of harm to facilitate implementation of existing recommendations: viewpoints from an EULAR task force. Ann Rheum Dis 2016; 75: 952-957.

21. Makol A, Davis JM $3^{\text {rd }}$, Crowson CS et al.: Time trends in glucocorticoid use in rheumatoid arthritis: results from a populationbased inception cohort, 1980-1994 versus 1995-2007. Arthritis Care Res (Hoboken) 2014; 66: 1482-1488.

22. Roubille C, Rincheval N, Dougados M et al.: Seven-year tolerability profile of glucocorticoids use in early rheumatoid arthritis: data from the ESPOIR cohort. Ann Rheum Dis 2017; 76: 1797-1802.

23. Cho SK, Sung YK: A paradigm shift in studies based on rheumatoid arthritis clinical registries. Korean J Intern Med 2019; 34: 974-981.

24. Combe B, Landewe R, Daien CI et al.: 2016 update of the EULAR recommendations for the management of early arthritis. Ann Rheum Dis 2017; 76: 948-959. 